\title{
SUPPLY CHAIN MANAGEMENT, COMPETITIVE ADVANTAGE AND ORGANIZATIONAL PERFORMANCE IN THE NIGERIAN MANUFACTURING SECTOR
}

\author{
Efosa Abiodun Oshodin*, Omorodion Omoregbe \\ Department of Business Administration, Faculty of Management Sciences, University of \\ Benin, Benin City, Edo State, Nigeria \\ efosa.oshodin@yahoo.com \\ omorodionomregbe@yahoo.com
}

\begin{abstract}
In this study, we examined the impact of supply chain management practices (SCMP): strategic supplier partnership, customer relationship, level of information shared, and information quality on competitive advantage and organizational performance in the Nigerian manufacturing sector. In so doing, this study was set out to find out if these practices generate conditions that promote higher or lesser competitive advantage and organizational performance. The survey research design was adopted because the characteristics of the respondents were fully captured in other to make important decisions. A total number of 122 were found usable out of 146 copies of questionnaire circulated. The structural equation modelling (SEM) was the estimation technique employed to measure the relationships among the various variables/constructs using AMOS 22.0. It was found out that the four predictors (strategic supplier partnership, customer relationship, level of information shared, information quality) of SCMP had significant impact on organizational performance. The study also revealed that of the four independent variables, three (strategic supplier partnership, customer relationship, and level of information shared) had significant impact on competitive advantage, while information quality had no significant impact on competitive advantage. In response to our research questions, we concluded that the four constructs or predictors generate conditions that promote higher competitive advantage and organizational performance in the Nigerian manufacturing sector. The study recommended that manufacturing organizations should share quality, timely and accurate information to ensure their product offerings can be altered to meet customers while offering competitive prices. The study further recommended that organizations should assist its suppliers to improve product quality; regularly relate with clients to set dependability, receptiveness, and other standards; notify trading partners early when changing needs arises; and have fast product development.
\end{abstract}

Keywords: Competitive Advantage, Organizational Performance, Supply Chain Management.

JEL classification: M11, M19.

\section{Introduction}

* Corresponding author: Efosa Abiodun Oshodin

Cite as:

Oshodin, E.A. and Omoregbe, O., 2021. Supply Chain Management, Competitive Advantage and Organizational Performance in the Nigerian Manufacturing Sector. Oradea Journal of Business and Economics, 6(2), pp. 57- 68.

http://doi.org/10.47535/1991ojbe129 
Today, supply chain management (SCM) is like a household name to many organizations. It has gained so much popularity and usage by firms. The question arises: why now is supply chain management a trending issue? Simple, the environment of business has changed rapidly and this includes globalization, technological innovation, severe competition, heightened customers' expectation, geopolitical factors, and so on (Mentzer, et al., 2001). Supply chain involves series of partners such as the organizations, the suppliers and the customers (Li, Ragu-Nathan, Ragu-Nathan, and Rao, 2006). The suppliers seek to provide the best quality products and or services and to adhere strictly to contractual agreements. Customers basically seek quality and affordable products and/or services, in order to get full satisfaction. Adebayo (2012) identified firms in Nigeria that fall into these categories to include assemblers, sub-contractors or small part makers as part of a supply chain (Omoregbe and Adjaino, 2019). Managers must understand that their businesses are only part of the supply chains and that it is only with effective supply chains that they can gain competitive advantage. On that note, Omoregbe and Adjaino (2019) described supply chains as a means by which organizations with common interest come together with the purpose of adding value to end products. SCMP provide an organization a platform to outperform its competitors, be sensitive to both suppliers (upstream sector) and customers (downstream sector), build core competence, share quality information and enhance its performance.

In Nigeria like everywhere else, corporate environment is changing rapidly and organizations strive to seek ways to maximize the benefits associated with SCM in order to survive and where possible surpass competitors and the manufacturing sector is not limited. Manufacturing firms are in desperate need to boost their general performance especially its profits. In doing so, they acknowledge that poor partnership/relationship with its suppliers/customers and poor information among others can hinder the possibility of improving performance. In this light, this paper examines the level of effects of strategic supplier partnership, customer relationship, level of information shared, and information quality on competitive advantage and organizational performance in the Nigeria manufacturing sector.

\section{Literature Review}

\subsection{Supply Chain Management (SCM)}

SCM according to Mentzer et. al. (2001) is the synchronization of the customary business activities within an organization and its supply chain partners for advancing the strategic performance of the full supply chain. Karimi and Rafiee (2014) viewed SCM as integrating the internal business functions of an organization and extending same to the external operations of its supply chain partners. This he believed will improve the competitive stance of the organization. Annan, Otchere and Amoako (2013) advocated that SCM should be part of an organization philosophy that takes a systemic view of the organization rather than being concerned with its business units separately. Wijetunge (2016) stated that implementation of the SCM is made possible by the network structure of the supply chain, the processes and the management team.

\subsection{Supply Chain Management Practices (SCMP)}

Several SCMP have been postulated by different authors with all having the same underlying aim of effectively coordinating the supply chain performance to achieve its desired goal. Li, et. al (2006) recognized strategic alliance with suppliers, effective relationship with customers, information viability (in terms of the level and quality) and postponement as practices of SCM; Annan, et al (2013) identified product superiority, shared problem-solving with partners, total quality, customer interface, periodic appraisal of performance as practices of SCM. Prabusankar and Prabusankar (2017) mentioned supplier, customer and 
internal integration, information exchange, and postponement as practices of SCM; Mutuerandu (2014) saw practices of SCM the same way as Li, et. al. (2006), Sah, Habidin, Latip, and Salleh, (2014) and Wijetunge (2016) viewed SCM practices as customer and leadership centered, internal lean practice and information quality. In this study, we adopted the four common SCM practices: strategic supplier partnership, customer relationship, level of information shared, and information quality as our second order constructs of our independent variable. In Nigeria, these SCM practices are salient and can be easily identified in organizations.

\section{Strategic Supplier Partnership (SSP)}

This describes the strategic partnership between a firm and its partners in the supply chain. It allows for the success of both the firm and the suppliers of products/services. It is premeditated to influence the competencies of all organizations ( $\mathrm{Li}$, et. al 2006). A strategic partnership is characterized with mutual planning/goal setting activities, long-standing relationships, product quality, joint-solving problem ability, and new product development processes. The essence of the partnership is to encourage and promote shared benefits including technological, products and markets benefits.

$\mathrm{Ho}_{1}$ : There is no significant association between SSP, competitive advantage and organizational performance.

\section{Customer Relationships (CR)}

The essence of customer relationship is to continuously improve the satisfaction level of customers. It involves managing their complaints, improving and preserving long term strategic relationship. $\mathrm{Li}$, et. al. (2006) argued that maintained relationships distinguishes a company product from other competitors and commands brand loyalty thereby positioning the organization in a more advantage point, financially and non-financially.

$\mathrm{Ho}_{2}$ : Firms with high levels of customer relationship do not have same of competitive advantage and organizational performance

\section{Level of Information Sharing}

Extent of information sharing in this context in is about the quantity of information to be shared among supply chain partners. Information could range from corporate proprietary data to logistics, customer, product and market data to enable supply chain partners perform effectively. Childerhouse and Towill (2003) considered exchange of information as a crucial part of any supply chain relationship. Information sharing must be promptly done giving consideration to time to enable the supply chain partners to satisfy customer needs.

$\mathrm{Ho}_{3}$ : Firms with high levels of information sharing do not have same of competitive advantage and organizational performance.

\section{Quality of Information Exchange}

Feldmann and Muller (2003) posited that information shared by partners in the supply chain must be void of any form of opportunistic behaviour and divergent interest. Information distorted can adversely affect the performance of the supply chain process. According to Li, et. al (2006) tampered information will adversely affect suppliers, customers as well as competitors. Most organizations are unwilling to give complete information because it is believed that full information disclosure invariably means perceived/apparent loss of authority; as such they resort to distorting of information. For supply chain management to be effective, information shared must be adequate, reliable, timely, accurate and complete. $\mathrm{Ho}_{4}$ : Information quality is independent of competitive advantage and organizational performance.

\section{Empirical Review}

The study of $\mathrm{Li}$, et. al (2006) in Toledo, United States of America developed five concepts as sub-constructs of SCM practices in their study on supply chain management, competitive 
advantage and organizational performance. 196 firms constituted the sample size for the study. Data were analyzed using structural equation model via AMOS 22.0 software. Structural equation modelling allows for hypothesized relationship involving more than one dependent variable to be analyzed. They however found out that only postponement had a low influence on organizational performance, while competitive advantage positively affects organizational performance.

Adebayo (2012) conducted a study that investigated the extent to which Nigerian manufacturing companies SCM practices impact organizational performance. Sample was collected from 31 companies and analyzed using correlation and regression analysis. Result showed that SCMP have a direct and positive effect on organizational performance.

Adebambo, Mcisn, and Tosin (2012) in their study examined SCM practices in Nigeria on firm's competitive advantage. Data were retrieved from 115 manufacturing companies and analyzed using multiple regression technique. The outcome indicated a positive association between SCM practices and competitive advantage. Recommendation was focused on the need for improvement on SCM practices that directly impact competitive advantage.

Babatunde, Gbadeyan, and Bamiduro (2016) examined the level of impact SCM practices have on market performance of merchants of petroleum products in Nigeria. Using the stratified and convenience sampling, 126 respondents were selected to form the sample size. Data were analyzed using Pearson correlation matrix and multiple regression technique. The outcome revealed that SCMP impact on market performance of the organization. They recommended a healthy relationship must exist with customers and suppliers to improve organizational performance.

Prabusankar and Prabusankar (2017) studied the impact of SCMP on competitive advantage of manufacturing firms in India. Using a sample size of 300, data were analyzed using via SPSS. Result showed that all sub-construct of SCM practices impacts positively on competitive advantage. He recommended that suppliers be involved in the goal and planning process and that information be shared adequately and timely.

Gbadeyan, Boachie-Mensah and Osemene (2017) embarked on a study to determine the effect of SCMP in designated private hospitals in Ilorin, Nigeria. They adopted a qualitative and descriptive research design, where 10 out of 58 private hospitals constituted the sample size. Using PLS method the result showed there exist no strong and positive impact on the dependent variable, organizational performance. They concluded that proper implementation of SCM will not only boost competitive advantage but will result in greater satisfaction of patients. They recommended hospitals to diversify its sources of equipment and materials for better procurement of needed supplies.

Omoregbe and Adjaino (2019) examined the impact SCMP have on organizational competitive advantage in table water industry in Edo State. A survey research was adopted were 248 respondents from 50 table water firms constituted the sample size. Analysis of the data was done using correlation matrix and OLS via SPSS 22.0. The study revealed that SCMP is operational in the table water firms and that there exists a positive relationship with the competitive of the selected firms. They recommended managers to be more committed to its relationship with its stakeholders or partners.

\section{Theoretical Framework}

The Resource Based View (RBV) best aligns with this study. This theory assumes that resources are means to achieving competitive advantage and superior organizational performance. Proponents of RBV are of the school of thought that rather than acquiring novel resource in exploiting external opportunities, exhausting internal resources will be beneficial. 


\section{Methodology}

The research design used was the survey research design. It was chosen because we employed the use of a structured questionnaire to elicit information from respondents. The population consists of all the manufacturing firms in Edo/Delta State of Nigeria listed in the bulletin of the Manufacturers Association of Nigeria, (MAN), Edo/Delta. According to the 2019 Annual Reports of the Manufacturers Association of Nigeria, Edo/Delta Branch, the total number of Edo/Delta membership data of manufacturing organizations is 73 . Due to the smallness of the population, the sample size of 146 was used. This was arrived at because we distributed a minimum of two copies questionnaire to each organization.

The analysis was made possible using the following software packages: Microsoft Excel 2010 - for data coding and screening; SPSS (SPSS 23.0) - for descriptive and correlation analysis; and AMOS 22.0 for multivariate analysis techniques. The structural equation modelling (SEM) was used to analyze the relationship between measured variables and latent constructs. The justification for this is that it is useful in estimating models that have more than one dependent variable simultaneously. The measurement model denotes the confirmatory factor analysis (CFA), in that, it postulates the pattern by which each measure loads on a specific factor. It basically authenticates the model rather than explaining relationships between constructs.

This study provides us with three models: first, the model that explained the functional relationship between SCM practices and organizational performance; the second model explained the functional relationship between SCM practices and competitive advantage, while the third model explained the functional relationship between competitive advantage and organizational performance. The three models were regressed and stated functionally as:

Supply Chain Management Practices and Organizational Performance

$O P=f(S S P, C R, I Q, I E)$.

Econometrically, the model can be specified as:

$O P_{i}=\alpha_{0}+\alpha_{1} S S P_{i}+\alpha_{2} C R_{i}+\alpha_{3} I Q_{i}+\alpha_{4} I E_{i}+\varepsilon$

Supply Chain Management Practices and Competitive Advantage

$C A=f(S S P, C R, I Q, I E)$.

Econometrically, the model can be specified as:

$C A_{i}=\beta_{0}+\beta_{1} S S P_{i}+\beta_{2} C R_{i}+\beta_{3} I Q_{i}+\beta_{4} I E_{i}+\varepsilon_{j}$

Competitive Advantage and Organizational Performance

$O P=f(C A)$

Econometrically, the model can be specified as:

$\mathrm{OP}_{\mathrm{i}}=\lambda_{0}+\lambda_{1} \mathrm{CA}_{\mathrm{i}}+\varepsilon$

Where:

$\mathrm{OP}=$ Organizational Performance; CA = Competitive Advantage; SSP = Strategic Supplier Partnership; $C R=$ Customer Relationship; IQ = Quality of Information; IE = Level of Information Exchange; $\varepsilon=$ Error term; $\alpha_{0}=$ Parametric constant; $\beta_{0}=$ Parametric constant; $\lambda_{0}=$ Parametric constant; $\alpha_{1}, \alpha_{2}, \alpha_{3}, \alpha_{4}=$ Parametric coefficients of elasticity of supply chain management practices displaying degrees of explanation power about organizational performance; $\beta_{1}, \beta_{2}, \beta_{3}, \beta_{4}=$ Parametric coefficients of elasticity of supply chain management practices displaying degrees of explanation power about competitive advantage; $\lambda_{1}=$ 
Parametric coefficients of elasticity of competitive advantage displaying degrees of explanation power about organizational performance.

$\begin{array}{ll}\text { A priori sign/ expectation: } & \alpha_{1}>0, \alpha_{2}>0, \alpha_{3}>0, \alpha_{4}>0 \ldots \ldots \ldots \\ & \beta_{1}>0, \beta_{2}>0, \beta_{3}>0, \beta_{4}>0 \ldots \ldots \ldots \\ & \lambda_{1}>0\end{array}$

\section{Empirical Analysis and Result}

\section{Validity and Reliability of Instrument}

The validity and reliability of our variables is as given below:

The reliabilities of SCM practices, CA, and OP were evaluated with Cronbach's Alpha. According to Nunnally (1978), construct values above the threshold of 0.70 is acceptable.

Table 1: Means, standard deviations, correlations and reliability of (a) SCM practices, (b) competitive advantage, and (c) organizational performance.

\begin{tabular}{|c|c|c|c|c|c|c|c|c|}
\hline Variables & Mean & SD & 1 & 2 & 3 & 4 & 5 & Reliability \\
\hline \multicolumn{9}{|l|}{ (a) SCM practices } \\
\hline $\begin{array}{l}\text { 1. Strategic supplier } \\
\text { partnership }\end{array}$ & 4.29 & 0.454 & 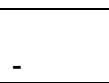 & & & & & 0.780 \\
\hline $\begin{array}{ll}2 . & \text { Customer } \\
\text { relationship } & \end{array}$ & 4.02 & 0.445 & $0.219^{*}$ & - & & & & 0.737 \\
\hline $\begin{array}{l}\text { 3. Level of information } \\
\text { exchange }\end{array}$ & 4.26 & 0.511 & 0.092 & $0.211^{*}$ & - & & & 0.750 \\
\hline $\begin{array}{l}\text { 4. Quality of information } \\
\text { exchange }\end{array}$ & 4.35 & 0.002 & 0.123 & $.235^{* \star}$ & $.282^{* \star}$ & - & & 0.799 \\
\hline \multicolumn{9}{|l|}{$\begin{array}{l}\text { (b) Competitive } \\
\text { Advantage }\end{array}$} \\
\hline 1. Price/Costs & 4.37 & 0.645 & - & & & & & 0.722 \\
\hline 2. Quality & 4.79 & 0.411 & $.261^{* \star}$ & - & & & & 0.725 \\
\hline 3. Dependable delivery & 4.37 & 0.484 & 0.063 & $.194^{*}$ & - & & & 0.751 \\
\hline 4. Product Innovation & 4.15 & 0.712 & $.186^{*}$ & 0.057 & $.193^{*}$ & - & & 0.731 \\
\hline 5. Time to market & 4.32 & 0.671 & $.260^{* *}$ & $.249^{* *}$ & 0.163 & $.271^{* *}$ & - & 0.713 \\
\hline \multicolumn{9}{|l|}{$\begin{array}{l}\text { (c) Organizational } \\
\text { Performance }\end{array}$} \\
\hline 1. Market performance & 4.20 & 0.559 & - & & & & & 0.704 \\
\hline $\begin{array}{l}\text { 2.Financial } \\
\text { performance }\end{array}$ & 4.12 & 0.569 & $.258^{\star \star}$ & - & & & & 0.747 \\
\hline
\end{tabular}

**. Correlation is significant at the 0.01 level (2-tailed).

*. Correlation is significant at the 0.05 level (2-tailed).

Source: Researchers' computation (2021)

\section{Confirmatory Factor Analysis}

The four constructs of the independent variables were represented using 22 items with their respective loadings all above 0.70 . Also, the five constructs of competitive advantage were represented by 16 items showed that their loadings are above 0.70 , and lastly the seven constructs of organizational performance revealed that just one was below the borderline of 0.70 , by implication, the factors below sufficiently demonstrate sufficient convergent validity. 
Table 2: Pattern Matrix

\begin{tabular}{|c|c|c|c|c|c|}
\hline Item & F1-SSP & F2-CR & F3-IE & F4-IQ & \\
\hline \multicolumn{6}{|l|}{ (a)SCM Practices } \\
\hline SCMP/SSP1 & 0.785 & & & & \\
\hline SCMP/SSP2 & 0.762 & & & & \\
\hline SCMP/SSP3 & 0.651 & & & & \\
\hline SCMP/SSP4 & 0.728 & & & & \\
\hline SCMP/SSP5 & 0.818 & & & & \\
\hline SCMP/SSP6 & 0.677 & & & & \\
\hline SCMP/CR1 & & 0.680 & & & \\
\hline SCMP/CR2 & & 0.728 & & & \\
\hline SCMP/CR3 & & 0.779 & & & \\
\hline SCMP/CR4 & & 0.730 & & & \\
\hline SCMP/CR5 & & 0.813 & & & \\
\hline SCMP/IE1 & & & 0.833 & & \\
\hline SCMP/IE2 & & & 0.804 & & \\
\hline SCMP/IE3 & & & 0.747 & & \\
\hline SCMP/IE4 & & & 0.702 & & \\
\hline SCMP/IE5 & & & 0.779 & & \\
\hline SCMP/IE6 & & & 0.747 & & \\
\hline SCMP/IQ1 & & & & 0.625 & \\
\hline SCMP/IQ2 & & & & 0.782 & \\
\hline SCMP/IQ3 & & & & 0.758 & \\
\hline SCMP/IQ4 & & & & 0.717 & \\
\hline SCMP/IQ5 & & & & 0.736 & \\
\hline \multicolumn{6}{|l|}{ Item } \\
\hline (b) Competitive Advantage & F1-PC & F2-QL & F3-DD & F4-PI & F5-TM \\
\hline $\mathrm{CA} / \mathrm{PC} 1$ & 0.829 & & & & \\
\hline $\mathrm{CA} / \mathrm{PC} 2$ & 0.663 & & & & \\
\hline CA/QL1 & & 0.799 & & & \\
\hline CA/QL2 & & 0.790 & & & \\
\hline CA/QL3 & & 0.697 & & & \\
\hline CA/QL4 & & 0.800 & & & \\
\hline CA/DD1 & & & 0.755 & & \\
\hline CA/DD2 & & & 0.694 & & \\
\hline CA/DD3 & & & 0.744 & & \\
\hline
\end{tabular}


Oradea Journal of Business and Economics, Volume VI, Issue 2

Published in September 2021

\begin{tabular}{|l|l|l|l|l|l|}
\hline Item & F1-SSP & F2-CR & F3-IE & F4-IQ & \\
\hline CA/PI1 & & & & 0.751 & \\
\hline CA/PI2 & & & & 0.728 & \\
\hline CA/PI3 & & & & 0.729 & \\
\hline CA/TM1 & & & & & 0.685 \\
\hline CA/TM2 & & & & & 0.800 \\
\hline CA/TM3 & & & & & 0.727 \\
\hline CA/TM4 & & & & & 0.732 \\
\hline Item & & & & & \\
\hline (c) Organizational Performance & F1-MP & F2-FP & & & \\
\hline OP1 & 0.795 & & & & \\
\hline OP3 & 0.734 & & & & \\
\hline OP4 & 0.760 & & & & \\
\hline OP7 & 0.742 & & & & \\
\hline OP2 & & 0.770 & & & \\
\hline OP5 & & 0.692 & & & \\
\hline OP6 & & 0.766 & & & \\
\hline
\end{tabular}

Source: Researchers' computation (2021)

\subsection{Results for the Structural Model}

The hypothesized relationships were represented using path diagram to describe the relationship among the constructs (observed and latent variables) using AMOS 22.0. From our analysis, we recorded significant loadings in the sub-construct. Below is the path diagram (Figure 1): 


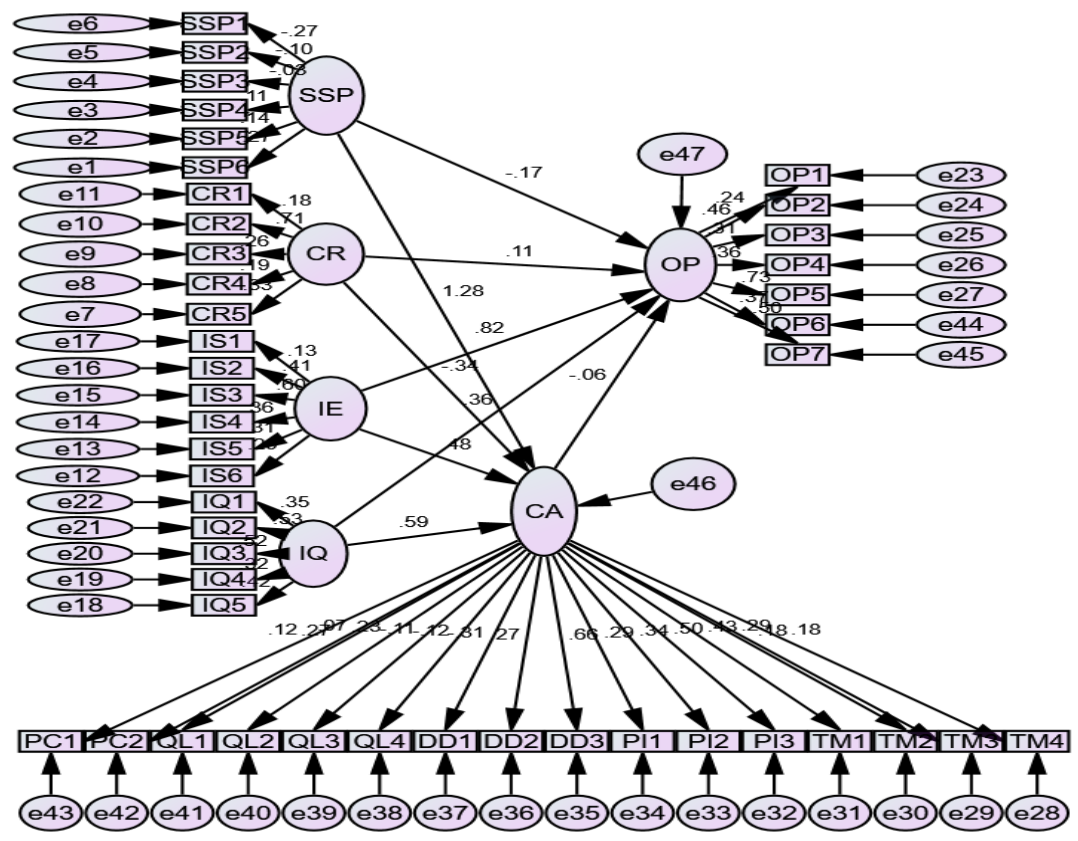

Figure 1: Path diagram

Table 3: Estimates of Regression Weights

\begin{tabular}{|c|c|c|c|c|c|c|}
\hline & & & Estimate & S.E. & C.R. & $\mathbf{P}$ \\
\hline $\mathrm{CA}$ & $<<--$ & $\mathrm{IQ}$ & .500 & .237 & 2.113 & .035 \\
\hline CA & $<---$ & IE & .659 & .123 & 5.379 & $* * *$ \\
\hline CA & $<---$ & CR & .598 & .164 & 3.649 & $* * *$ \\
\hline CA & $<---$ & SSP & .677 & .312 & 2.169 & .030 \\
\hline OP & $<---$ & SSP & .741 & .104 & 7.159 & *** \\
\hline OP & $<---$ & CR & .859 & .150 & 5.728 & $* * *$ \\
\hline OP & $<---$ & IE & .885 & .100 & 8.872 & $* * *$ \\
\hline OP & $<---$ & IQ & .959 & .511 & 1.875 & .061 \\
\hline OP & $<---$ & $\mathrm{CA}$ & 1.475 & .678 & 2.177 & .030 \\
\hline
\end{tabular}

Source: Researchers' computation (2021)

Table 3 above shows that the variables are significant with different levels of impact. However, the impact of the quality of information on organizational performance cannot be said to be significant, because it has a value less than 1.96. Also, the report describes a positive relationship among the variables. There is a direct impact of SCM practices (SSP, $\mathrm{CR}$, and IE) on CA and OP. The report also showed that the three significant variables on SCM practices have a relatively higher impact on organizational performance than on 
competitive advantage, while IE and CR have more impact than SSP on competitive advantage.

\subsection{Test of Hypotheses}

The outcomes of the proposed SEM analysis are presented in Table 4 demonstrating support for the hypotheses. It displays the result of the causative association between the constructs. The outcome as shown in Table 4 signifies the position of this study. The t-values are all above the threshold of 1.96 indicating support for the hypotheses.

Table 4: Result for proposed structural equation model

\begin{tabular}{|c|c|c|c|c|}
\hline Hypotheses & Relationship & t-statistics & p-value & Result \\
\hline \multirow{2}{*}{$\mathrm{H}_{1}$} & SSP-OP & 2.113 & .035 & Supported \\
\hline & SSP-CA & 7.159 & $\star \star \star$ & Supported \\
\hline \multirow{2}{*}{$\mathrm{H}_{2}$} & CR-OP & 5.379 & $\star \star \star \star$ & Supported \\
\hline & CR-CA & 5.728 & $* \star *$ & Supported \\
\hline \multirow[b]{2}{*}{$\mathrm{H}_{3}$} & IE-OP & 3.649 & $* \star *$ & Supported \\
\hline & IE-CA & 8.872 & $\star \star \star *$ & Supported \\
\hline \multirow{3}{*}{$\mathrm{H}_{4}$} & IQ-OP & 2.169 & .030 & Supported \\
\hline & IQ-CA & 1.875 & .061 & Unsupported \\
\hline & CA-OP & 2.177 & .030 & Supported \\
\hline
\end{tabular}

Source: Researchers' computation (2021)

The statistical significance of hypothesis 1 confirms that strategic supplier partnership significantly impacts competitive advantage (7.159) and organizational performance (2.113). Hypothesis 2 revealed that customer relationship impacts positively on competitive advantage (5.728) and organizational performance (5.379). Hypothesis 3 showed that information exchange impacts competitive advantage (8.872) and organizational performance (3.649) and finally, hypothesis 4 showed that information quality impacts significantly on organizational performance while there is no impact on competitive advantage. The third model indicates that there exists a significant relationship between competitive advantage and organizational performance.

\section{Conclusion}

Supply chain management practices can be said to be vital for organizational performance. Considering the dynamic and complex environment of business, locally and globally and the deadly impact of coronavirus, supply chain management practices can aid effective performance and growth of organizations. This study found out that firms with higher levels of strategic supplier partnership, customer relationship, and level of information have higher levels of competitive advantage and organizational performance, while firms with higher levels of information quality have higher levels of organizational performance but do not have higher levels of competitive advantage. This study therefore recommended that organizations should share quality, timely and accurate information to ensure their product offerings can be altered to meet customers while offering competitive prices. The study further recommended that organizations should assist its suppliers to improve product quality; regularly relate with clients to set dependability, receptiveness, and other standards; inform partners promptly of changing needs; and have fast product development. 


\section{References}

Adebambo, S., Mcisn, M., and Adebayo, Toyin, I. 2012. Firm's competitiveness through supply chain responsiveness and supply chain management practices in Nigeria. British Journal of Arts and Social Sciences, 10(1), pp.42-52.

Adebayo, I.T., 2012. Supply chain management (SCM) practices in Nigeria today: impact on SCM performance. European Journal of Business and Social Sciences, 1(6), pp.107-115.

Annan, J., Otchere, A.F., and Amoako, A.D., 2013. Assessing Supply Chain Management Practices on Organizational Performance; a Case Study of the West African Examinations Council (Waec), Ghana National Office, Accra, American Based Research Journal, 2(6), pp.36-48, DOI: $10.5281 /$ zenodo.3408188.

Babatunde, B.O., Gbadeyan, R.A. and Bamiduro, J.A., 2015. Supply chain management practices and market performance: Evidence from selected major marketers of petroleum products in Nigeria. Pacific Journal of Science and Technology, 7(1), pp.129-139.

Byrne, B.M., 1998. Structural equation modeling with LISREL, PRELIS, and SIMPLIS: Basic concepts, applications, and programming. New York: Imprint Psychology Press, DOI https://doi.org/10.4324/9780203774762.

Childerhouse, P. and Towill, D.R., 2003. Simplified material flow holds the key to supply chain integration. Omega, 31(1), pp.17-27, DOI: 10.1016/S0305-0483(02)00062-2.

Feldmann, M. and Müller, S., 2003. An incentive scheme for true information providing in supply chains. Omega, 31(2), pp.63-73, DOI: 10.1016/S0305-0483(02)00096-8.

Gbadeyan, R.A., Boachie-Mensah, F.O. and Osemene, O.F., 2017. Effect of supply chain management on performance in selected private hospitals in Ilorin, Nigeria. International Journal of Economic Behavior, 7(1), pp.99-116.

Hair, J.F., Anderson, R.E., Tatham, R.L., and Black, W.C., 2010. Multivariate data analysis. 7th ed. New Jersey: Prentice-hall, Englewood Cliffs.

Hu, L.T. and Bentler, P.M., 1999. Cutoff criteria for fit indexes in covariance structure analysis: Conventional criteria versus new alternatives. Structural Equation Modeling: A Multidisciplinary Journal, 6(1), pp.1-55, https://doi.org/10.1080/10705519909540118.

Jöreskog, K.G. and Sörbom, D., 1993. LISREL 8: Structural equation modeling with the SIMPLIS command language. Scientific Software International.

Karimi, E. and Rafiee, M., 2014. Analyzing the impact of supply chain management practices on organizational performance through competitive priorities (case study: Iran pumps company). International Journal of Academic Research in Accounting, Finance and Management Sciences, 4(1), pp.1-15, DOI:10.6007/IJARAFMS/V4-I1/503.

Li, S., Ragu-Nathan, B., Ragu-Nathan, T.S. and Rao, S.S., 2006. The impact of supply chain management practices on competitive advantage and organizational performance. Omega, 34(2), pp.107-124, https://doi.org/10.1016/j.omega.2004.08.002.

Mentzer, J.T., DeWitt, W., Keebler, J.S., Min, S., Nix, N.W., Smith, C.D. and Zacharia, Z.G., 2001. Defining supply chain management. Journal of Business Logistics, 22(2), pp.1-25, https://doi.org/10.1002/j.2158-1592.2001.tb00001.x.

Mutuerandu, M., 2014. Impact of supply chain management practices on organizational performance: a case study of HACO industries limited (Kenya). IOSR Journal of Business and Management (IOSR-JBM), $\quad 16(4), \quad$ pp. https://doi.org/10.6084/M9.FIGSHARE.1118905.

Nunnally, J.C., 1978. An overview of psychological measurement. Clinical Diagnosis of Mental Disorders, pp.97-146, DOI: 10.1007/978-1-4684-2490-4_4.

Omoregbe, O. and Adjaino, O. V., 2019. Supply chain management practices and competitive advantage in selected Nigerian table water industry in Edo State. International Journal of Entrepreneurship Studies (IJES), 8(2), pp.38-63.

Prabusankar, R., 2017. Impact of Supply Chain Management Practices On Competitive Advantage of Small Manufacturing Firms In Coimbatore District'. International Journal of Mechanical Engineering and Technology, 8(10), pp.836-843. 
Sah, M.A.M., Habidin, N.F., Latip, N.A.M. and Salleh, M.I., 2014. A review of structural relationship between supply chain management and organizational performance in Malaysian automotive industry. Universal Journal of Industrial and Business Management, 2(1), pp.1-5, DOI: 10.13189/ujibm.2014.020101.

Wijetunge, W.A.D.S., 2017. The role of supply chain management practices in achieving organizational performance through competitive advantage in Sri Lankan SMEs. International Journal of Management and Applied Science, 3(1), pp.81-88, http://iraj.doionline.org/dx/IJMAS-IRAJ-DOIONLINE-6811.

\section{Bio-note:}

Omoregbe Omorodion is a postdoctoral student in University of Benin, Department of Business Administration and member of the editorial board of the Department of Business Administration and Faculty of Management Sciences University of Benin. As a postdoctoral student, Omoregbe Omorodion is focused on global and operations management of organizations. He published several papers in prestigious national and international journals and participated in numerous national and international conferences presenting the result of these studies.

Oshodin Efosa is a postdoctoral student in University of Benin, Department of Business Administration and member of the editorial board of the Department of Business Administration, University of Benin. As a postdoctoral student, Oshodin Efosa is focused on business process outsourcing and supply chain performance/management of organizations. He published numerous papers in prestigious national and international journals and participated in numerous national conferences presenting the result of these studies. 